MANTHAN: Journal of Commerce and Management Volume 4, Issue 2, July-December 2017, pp. 137-152 doi: 10.17492/manthan.v4i02.11866

\title{
The Evolving Framework of Determinants of Foreign Direct Investment: A Review of Literature
}

\author{
Rahul Bhasin* and KV Bhanu Murthy**
}

\begin{abstract}
The last two decades have witnessed intense competition among countries, particularly developing economies, to attract foreign direct investment (FDI). This is because FDI fills the gap between desired investment and domestic private investment and helps them to acquire new technology and managerial skills. This paper attempts to understand the evolution of FDI theory along with changes in the significance of determinants of FDI over a period of time. An analysis of extant literature shows that factors such as market size and per capita incomes have remained important determinants of FDI decisions both traditionally as well as in contemporary times. However, some factors such as resources, trade openness and FDI openness have now become secondary factors influencing FDI. Other factors which were earlier secondary but have now gained prominence as FDI determinants are infrastructure; institutional factors such as corruption and political stability; and tax related variables. The above review provides insights into changing aspects of FDI decision-making and useful inputs to policy makers regarding the areas which need focus for creating a congenial climate for FDI.
\end{abstract}

Keywords: Foreign direct investment; Eclectic theory; Globalisation; Market size; Trade openness; FDI openness; Infrastructure.

\subsection{Introduction}

The wave of globalisation that has swept the world in the last two decades has opened many national markets for international business. Global private investment, in most part, is now made by multinational corporations (MNCs) that play a major role in world trade and investments because of their demonstrated management skills, technology, financial resources and related advantages.

*Corresponding author; Ph. D. Research Scholar, Mewar University, Chittorgarh, Rajasthan, India.(Email id: rahul_b12@rediffmail.com; rahulb1509@gmail.com)

**Professor, Delhi Technological University, Delhi, India; Formerly Dean, Faculty of Commerce and Business, Delhi School of Economics, University of Delhi, Delhi, India. (Email id: bhanumurthykv@yahoo.com) 
The beginning of the 21st century marked a tremendous growth of international investments in the form of foreign direct investment (FDI) along with the integration and openness of international markets. Foreign direct investment (FDI) which is the outcome of the mutual interests of multinational firms and host countries has received considerable attention in literature related to international business. The theoretical framework of FDI as well as the determinants of FDI have evolved considerably over a period of time. The positive growth effects of FDI cannot be taken for granted. The extensive literature on FDI and the heterogeneity in findings indicate that FDI decisions depend on time-varying and location-specific factors. For example, opening up early to FDI inflows, combined with close integration into world trade, seems to have strengthened the FDI/growth nexus. This then implies that small and developing economies can benefit from positive growth effects of FDI as much as large and more advanced developing countries. To derive the intended benefits of FDI, countries must identify the factors which influence the decision making of MNCs in choosing a particular location for FDI. This paper attempts to understand the evolution of FDI theory along with changes in the significance of determinants of FDI over a period of time.

\subsection{Theoretical Framework}

One of the first theories to embed FDI in its framework was the 'Market Imperfection Theory'. The paradigm of market imperfection originated with the Industrial Organization theory of Bain (1956) which postulated that industries with few competitors and high entry barriers reap above-normal returns thereby creating an imperfect market. In a perfectly competitive market, firms produce homogeneous products and enjoy the same level of access to factors of production. Hence one firm cannot earn greater profits as compared to others in the market. However, the Industrial Organization theory discusses the reality of imperfect competition where firms gain different types of competitive advantages and each to varying degrees (Bain, 1956; Porter, 1985).

It was Hymer (1970) who extended this argument in the context of foreign markets. The market imperfections theory given by Hymer states that firms constantly seek market opportunities and their decision to invest overseas in other markets can be seen as a strategy to capitalize on certain capabilities not shared by competitors in those foreign markets (Hymer, 1970). These capabilities or advantages of firms are explained by market imperfections for products and factors of production. While the Market Imperfections theory offers some explanation of overseas investment, it does not explain 
why foreign production is considered the most desirable means of harnessing the firm's advantage, when other alternatives such as exports.

Thereafter, the International Product Life Cycle theory propounded by Raymond Vernon states that the locus of production by a firm changes as a product goes through different stages of its life cycle (Vernon, 1966). During the early stages of production, the production is kept in the home country and closer to the centre of decision making. Any demand for the firm's product in the foreign market is met through exports initially. However, as the product enters the maturity stage, new competitors start emerging in different host countries, motivated by higher profit potential. Perceiving this potential threat, the firm transfers its production facility to some of these markets in order to strengthen its market position. In addition, the maturity of the product makes price an important competitive weapon. In such cases, production facilities may be relocated to countries where cost of production is low so that there is an overall reduction in the price of the product. While Vernon's theory effectively explains the location choice of investment based on stages of product's life cycle, it still does not address the issue of preference for FDI over alternative modes of foreign entry such as exporting and licensing.

An important theory which gained prominence over others in terms of explaining the phenomenon of FDI was the 'Internalization theory'. The concept of internalization has been extensively investigated by Buckley and Casson $(1976,1985)$ and Buckley $(1982,1988)$. The Internalization theory propounds that firms choose to develop their own internal markets whenever transactions can be made at lower cost within the firm. Thus, firms grow by internalizing international markets for intermediate products such as firm-specific knowledge. In effect, internalization involves a form of vertical integration where new operations and activities, (formerly carried out by intermediate markets) are brought under the ownership and governance of the firm.

The above theories were further refined and new dimensions were added to explain overseas investment activities. Dunning's (1980) Eclectic Theory, popularly known as the OLI theory - Ownership advantage (O); Location advantage (L); and Internalization advantage (I) suggests that the propensity of a firm to initiate foreign production will depend on the firm-specific ownership advantages $(\mathrm{O})$; specific attractions of its home country compared with resource implications and advantages of locating in another country (L); and lower cost of developing internal markets (I). This theory makes it explicit that resource differentials and the advantages of the firm play an important part in determining overseas investment activities.

While the first and third conditions are firm-specific determinants of FDI, the second is location-specific and has a crucial influence on host country's inflows of FDI. 
If only the first condition is met, the firms will rely on exports, licensing or the sale of patents to service a foreign market. In the presence of internalization incentives (e.g., protection from supply disruptions and economies of common governance), FDI becomes the preferred mode of servicing foreign markets but only in the presence of location-specific advantages. Within the trinity of conditions, for FDI to occur, locational determinants are the only ones that host governments can influence directly (UNCTAD, World Investment Report, 1998).

The location-specific (host country) determinants of FDI can be grouped into three broad categories: (i) national policy framework for FDI, (ii) business facilitation and (iii) economic determinants (UNCTAD, World Investment Report, 1998, p.90). Of these, economic determinants predominate. Policies are decisive in regulating FDI but once an enabling regulatory framework is in place, the economic factors become dominant. In the economic factors, FDI is further classified by the motives of multinational corporations as market-seeking, resource-seeking and efficiency-seeking FDI.

Resource-seeking FDI is motivated by the availability of natural resources (e.g., minerals, raw materials and agricultural products) in host countries. This type of FDI was historically important and remains a relevant source of FDI for various developing countries. However, on a world-wide scale, the relative importance of resource-seeking FDI has decreased significantly. The relative importance of market-seeking FDI is rather difficult to assess. Regarding the history of FDI in developing countries, various empirical studies have shown that the size and growth of host country markets were among the most important FDI determinants. It is debatable, however, whether this is still true with ongoing modernization. Traditionally, FDI was the only reasonable means to penetrate local markets in various developing countries, as there were heavy barriers to imports. However, in recent times, many developing countries have liberalised their import regime, thereby enabling TNCs to choose between exporting or undertaking FDI. As a consequence, purely market-seeking FDI may decline. Efficiency-seeking FDI, i.e. FDI motivated by creating new sources of competitiveness for firms and strengthening existing ones, may then emerge as the most important type of FDI. The intention of the efficiency-seeking firms is to take advantage of different culture, institutional arrangements, and economic systems and policies. Accordingly, the competition for FDI would be based increasingly on cost differences between locations, the quality of infrastructure and business-related services, the ease of doing business and the availability of skills. Obviously, this scenario involves major challenges for developing countries, ranging from human capital formation to the provision of business-related services such as efficient communication and distribution systems. 


\subsection{FDI Determinants: A Review of Literature}

There exists considerable literature on the factors that determine the FDI flows to a country. The existing literature includes a large number of surveys and case studies and a number of econometric studies. In general, they conclude that the main factors which drive FDI into a country have been market size (generally determined by a country's GDP and GDP per capita), openness, infrastructure quality, taxes and tariffs, labour costs and the degree of political and economic stability. However, the importance of these determinants vary across countries and regions. Further, the significance of determinants also changes over a period of time. This implies that factors which were earlier considered as secondary have now gained prominence as being primary determinants of investment decisions. Institutional factors is a case in point; institutional variables such as property freedom, intellectual property rights, corruption etc. which were not considered as FDI determinants in earlier studies are now gaining prominence. This paper attempts to present an extensive review of the extant literature on FDI determinants and understand the evolution and changing importance of FDI determinants over a period of time. Further, it also attempts to segregate the literature in FDI in terms of cross-country studies, regional studies and single country based studies.

\subsection{Aggregative studies}

This section reviews those studies that have examined FDI determinants at an aggregate level, for example, taking a group of economies similar characteristics, such as developed countries or developing countries. Singh and Jun (1995) expand on earlier studies of the determinants of foreign direct investment (FDI) by empirically analysing various factors including political risk, business conditions, and macroeconomic variables that influence direct investment flows to developing countries. Their first hypothesis tests if there is a structural difference between countries with high or low FDI flows. Employing a political risk index variable, they find that a qualitative index of political risk is a significant determinant of FDI flows for countries that have historically attracted high FDI flows. For countries that have not attracted such flows, organisational instability (proxied by work hours lost in industrial disputes) has a negative impact on investment flows. Singh and Jun then examine if the overall perception of favourable business operating conditions positively affect FDI flows. Using an operation risk index, tests of this second hypothesis show that a general qualitative index of business operation conditions is an important determinant of FDI in countries that receive high flows. This country group also shows a positive relationship between taxes on international transactions and FDI flows. Finally, examining the causality between 
exports and FDI flows, they find that exports are a significant determinant of FDI flows for countries in which FDI is high. This hypothesis is supported by standard regression analysis and by Granger causality tests. Export orientation is the strongest variable for explaining why a country attracts FDI. Wei (1997) studies the effect of corruption on FDI covering bilateral investment from 14 source countries to 45 host countries during 1990-91. His findings show that a rise in either the tax rate on MNCs or the corruption level in the host country reduces inward FDI.

Gastanaga et al. (1998) identify the relative importance of host country reforms on foreign investment across a sample of less developed countries (LDCs). The various policy/institutional variables examined for the purpose include corporate tax rates, tariff rates, degree of openness to international capital flows, exchange rate distortions, contract enforcement, nationalisation, bureaucratic delay and corruption. The effects of such policies are analysed in a multivariate regression analysis with panel methods for 49 LDCs over 1970-95. The size of country effect is dealt with by defining the dependent variable in terms of FDI per units of GDP. Gastanaga et al. first use crosssection analysis for $23 \mathrm{LDCs}$ to estimate the effects of policy variables under study. The results, in general, show significant effects of most variables including tax rates, tariff rates, degree of openness to international capital flows, GDP growth rate, contract enforcement, bureaucratic delay and corruption. Thereafter, regression is done using panel method with two different sources of FDI data (i.e., aggregate FDI inflows from 'International Financial Statistics' and FDI outflows from U.S. from the 'Bureau of Economic Analysis', U.S. Department of Commerce). The results indicate positive and significant effects of expected rate of growth and degree of openness to international capital flows. Further, corruption has a deleterious effect on FDI while exchange rate distortions in host countries do not seem to exert a significant detrimental influence on FDI. While the cross-section analysis show relatively significant negative, non-linear effects of corporate tax rates, the results with panel data show a significantly negative and linear influence of corporate taxes on FDI flows. Similarly, although the pure crosssection results indicate the effect of tariff rates on FDI to be positive, in the panel regression, the net effect of tariff rates on FDI-GDP ratios become negative. (Gastanaga et al. hold that whereas cross-sectionally and in the early part of the period, tariffjumping seemed to be an important motive for FDI, over time, in individual countries trade liberalisation has become the more important motive for FDI). Finally, institutional characteristics such as contract enforcement, nationalisation and bureaucratic delay are shown to have significant effects on FDI. Since the results from panel methods differ rather significantly in some respects from those obtained from pure cross-section 
analysis, Gastanaga et al. maintain that it may be misleading to examine the effects of policy variables on FDI exclusively on cross-section analysis.

Nunnenkamp (2001) focuses on location-specific determinants of FDI that can be influenced by host country governments. His classification of location-specific factors draws largely on UNCTAD's classification (UNCTAD, 1998). Accordingly, host country determinants of FDI are grouped into three broad categories, viz., the overall policy framework for FDI, economic determinants and business facilitation measures. The overall policy framework includes economic and political stability as well as regulations governing the entry and operations of MNCs. Noorbakhsh et al. (2001) argue that developing countries might enhance their attractiveness as locations for FDI by following policies that raise the level of local skills and build up human resource capabilities. Taking 36 developing countries from Africa, Asia and Latin America over the period 1980-94 and carrying out regression analysis, they find that human capital is a statistically significant determinant of FDI inflows.

Demirhan and Masca (2008) identify the determinants of FDI inflows in developing countries over the period 2000-2004 by using a cross-sectional data of 38 developing countries. Employing a cross-sectional econometric model, they conclude that per capita growth rate, infrastructure and openness positively affect FDI inflows while inflation rate and tax rate are negatively related to FDI inflows.

Kayam (2009) explore the home country determinants of outward FDI from 65 developing and transition countries in the period 2000-2006. Using a fixed effects estimation technique, the author finds that outward FDI from developing countries increases with increase in foreign competition in the domestic market resulting from inward FDI. Further, outward FDI from developing country MNEs is an escape response to the economic and political conditions of the home country. As government stability, bureaucracy quality and investment profile improves in the home country, FDI outflows decrease.

Das (2013) identifies the home country determinants of outward FDI from developing economies for the period 1996-2010, using a panel data econometric framework. The author concludes that country's level of economic development, political risk, globalisation and science and technology investments contribute significantly to outward FDI from developing countries. The author recommends that developing countries need to emphasise better political governance in order to prevent FDI outflow arising out of high domestic political risk. Science and technology investments also contribute to higher outward FDI, which is beneficial because it yields complementary benefits of internationalisation in the long-run. 
Lien and Filatotchev (2015) examine how subsidiary ownership factors affect FDI location decisions in emerging economies. They find that ownerships of blockshareholders in the parent firm (i.e., controlling family, non-family TMT members and institutional investors) and equity stake in a subsidiary owned by the parent company are positively associated with FDI location decisions in risky areas.

As can be seen from the above studies, in general, market size, government stability, FDI openness, economic development and human capital have been widely accepted as significant determinants of FDI flows.

\subsection{Regional studies}

This section reviews studies which have examined FDI determinants for a certain region of the world. Lucas (1993) examines the determinants of FDI flows in seven East and Southeast Asian economies (Indonesia, South Korea, Malaysia, Philippines, Singapore, Taiwan and Thailand) over the period 1960-87. He develops a theoretical model based on the derived demand for foreign capital of a profit maximising, multiple product monopolist. Two versions of the model are employed: a basic form containing only relative price and other endowment type variables; and an extended version to include interdependence in location decisions, a potential role for market size, expectations formation, and consideration of political risk and regulatory framework. The basic model is estimated in logarithmic and linear form separately for each country. FDI inflows are found to be less elastic with respect to costs of capital than to wages, and to be more elastic with respect to aggregate demand in export markets than domestic demand.

Asiedu (2002) finds the determinants of FDI to developing countries and analyses whether these variables have a differential impact on FDI flows to sub-Saharan Africa (SSA). She examines why SSA has been relatively unsuccessful in attracting FDI although the last decade of the twentieth century witnessed a dramatic increase in FDI to developing countries. She uses cross-sectional data on 71 developing countries about half of which are in SSA. First, cross-section regressions are carried out where the variables are averaged over the period 1988-97. Then, estimates are obtained using panel regressions where variables are averaged over three sub-periods: 1988-90, 1991-93 and 1994-97. The dependent variable is the ratio of net FDI flows to GNP which is contemplated as a function of return on investment in the host country, infrastructure development, openness of the host country, political risk and other factors such as inflation rate and growth rate of GDP. After examining the effect of these variables on FDI flows, Asiedu includes a dummy variable (AFRICA) to test whether countries in SSA, on an average, receive less FDI relative to countries in other regions. The results 
indicate that a higher return on investment and better infrastructure have a positive impact on FDI to non-SSA countries, but have no significant impact on FDI to SSA. Further, it is seen that trade openness promotes FDI to SSA and non-SSA countries although the marginal benefit from increased openness is less for SSA. The Africa dummy variable is found to be significant with a negative estimated coefficient, implying that countries in SSA, on an average, receive less FDI than countries in other regions by virtue of their geographical location, i.e., there is an adverse effect on FDI for being an African country. These results suggest that Africa is different and therefore, policies that have been successful in other regions may not be equally successful in Africa.

Baniak et al. (2002) focus on the links between macroeconomic and legal stability and the inflow of FDI. Focusing on some select transition economies (Georgia, Kyrgyzstan), their analysis shows that macroeconomic and legal instability and high volatility of fiscal and business regulations reduces the flow of FDI. Therefore, for flow of long-term foreign capital, a stable economic and institutional environment is needed.

Caetano and Galego (2009) examine the role of institutional and economic determinants of FDI in the European Union and MENA (Middle East and North Africa) countries. They use panel data regressions for 42 countries which include 17 MENA countries and 25 European countries over a nine year period (since mid-nineties) to investigate possible differences in the determinants of FDI performance in these regions. They take the inward FDI performance index as their dependent variable and include various institutional and macroeconomic variables as possible determinants of FDI. Their empirical analysis reveal that there are some significant differences on the institutional determinants of FDI performance such as investment freedom, government size and trade freedom which lead to different FDI performance of these regions.

Bhavan et al. (2011) investigate the determinants and growth effect of FDI in case of four South Asian countries over the period of 1995-2000. Employing a gravity model equation using panel data, they find that pulling, pushing and cyclical factors are significant determinants of FDI in South Asian countries. They also use a growth model equation to investigate growth effect of FDI in these countries and conclude that FDI in South Asian countries is significantly and positively associated with growth rate.

Kokouma and $\mathrm{Xu}$ (2013) explore the determinants and policies for attracting Chinese FDI to Africa by analysing the characteristics, trends and developments in the economic engagement between Guinea and China. They observe that investment in the region is attracted by an assessment of geographical location, corruption levels, infrastructure, income yields, and implementation of the policies by the governments. 
Youssouf (2017) examines the determinants of FDI in sub-Saharan African countries for the period 1985-2012. Employing linear dynamic panel model, he finds that the most important determinants are natural resources and market size and other determinants such as infrastructure, inflation, human capital, trade openness, political instability and corruption are not very significant determinants of FDI.

A review of studies which have regional samples of countries indicate that the significant determinants of FDI include market size, locational factors, infrastructure, corruption, investment freedom and trade freedom.

\subsection{Country based studies}

A large number of studies in FDI literature are country based studies focusing on trends and determinants of FDI inflows and outflows of specific countries. This section reviews some of those studies and identifies the determinants that emerge out of extant literature. Many of these studies have also focused on the effects of unconventional variables like taxation on both inbound and outbound foreign direct investment. Hartman (1984) performed an empirical analysis relating to the influence of domestic tax policy on FDI in the United States using annual time series data for the fifteen-year period 1965-1979. He estimated the effects on U.S. inbound FDI, of changes in the after-tax rates of return received by foreign investors in U.S. inbound FDI and by investors in U.S. capital generally. He also included, as an explanatory variable, the tax rate on U.S. capital owned by foreign investors relative to that owned by U.S. investors. His estimated models do not incorporate measures of U.S. withholding taxes, foreign income taxes, or rates of return on non-U.S. investments. Using the log of the ratio of FDI to U.S. GNP as the dependent variable, Hartman's results indicate that the FDI-GNP ratio increases as the after-tax rates of return rise and decreases as the relative tax rate on foreigners rises. The variables have the expected sign, though explanatory power was much better for investment financed by subsidiary retained earnings. These suggestive findings indicate that foreign investment in the US is strongly affected, in the manner predicted on the basis of the model, by changes in domestic tax policy and thus, taxes are an important determinant of FDI.

Boskin and Gale (1987) re-estimated Hartman's model using data over the period 1956-84. They studied aggregate U.S. inflows and outflows of foreign direct investment and found that a domestic tax policy change that increases domestic investment by $\$ 1$ will prompt $\$ 0.08$ to 0.27 of additional investment from abroad and deter $\$ 0.04$ of U.S. investment abroad. While their results vary across different specifications, they are qualitatively consistent with Hartman's findings. 
Loree and Guisinger (1995) examine the effects of policy and non-policy variables on the location of new U.S direct investment abroad (i.e., the equity component of FDI that flows to countries as distinct from reinvested earnings of existing affiliates) for two years: 1977 and 1982. The policy variables employed include performance requirements (such as exporting a minimum amount, importing no more than a certain amount etc.) and investment incentives (e.g., tax concessions, tariff concessions and subsidies). The non-policy variables examined are political stability, cultural distance, market characteristics, infrastructure and wage levels. Loree and Guisinger use the Benchmark Surveys of the U.S. Department of Commerce to gather comparative information on investment incentives received and performance requirements encountered by the foreign affiliates of U.S. parent firms in 48 countries. Their results show statistically significant effects for investment incentives, performance requirements and host country effective tax rates. Further, significance is also found for non-policy variables such as political stability, distance, GDP per capita and infrastructure.

Gropp and Kostial (2001) have found a strong link between FDI and the tax regime of a country by comparing a group of countries with the lowest tax rates to a group of countries with the highest tax rates. They observed that during the sample period (1988-97), countries in the low-tax group experienced much lower net FDI outflows relative to the high-tax group; net outflows in the low-tax group were about half those in the high tax group.

Teka (2014) study the determinants of FDI inflows in Ethopia which has significantly liberalised its trade and investment regime and is working towards creating an investment friendly infrastructure. The results of the study indicate that domestic and regional market, political and social stability, and investment incentives are significant determinants of FDI. However, corruption, exchange rate volatility, and lack of transparent policies have the potential to deter FDI in Ethiopia. Duong (2015) employ macro panel data on US FDI in developed countries during 1982-2010 to empirically investigate the influence of host country characteristics on FDI. Their results indicate that the stock of US FDI in a given FDI recipient is significantly determined by market size, lower relative tax rates, and risks in terms of the investment climate, corruption and the legal environment of the host country.

Sury (2003) examines the possible effects of domestic taxes and rates of return on FDI in India. Using the econometric models given by Hartman (1984) and Young (1988) for a sixteen-year sample period, i.e., 1985-2000, the effects of taxes on FDI in India are found to be quite strong. In general, the results show that an increase in the specific after-tax rate of return realised by foreign investors in India leads to an increase in foreign investment. Further, it has been found that an increase in the overall after-tax 
rate of return on capital in India leads to a fall in FDI. The results also indicate that a decline in the tax rate faced by an Indian investor relative to the tax rate faced by a foreign investor tends to cause a significant decrease in the level of foreign investment. Conversely, a change in India's tax policy which tends to diminish the tax rate faced by foreigners (e.g., a decrease in corporate income tax on foreign companies) provides strong encouragement to increase FDI in India. Therefore, FDI is elastic with respect to the relative net-of-tax return. Thus, the empirical analysis suggests that FDI in India is strongly affected, in the manner predicted on the basis of the models used, by changes in domestic tax policy.

Fukao and Wei (2008) examine the difference in determinants between horizontal and vertical FDI for the case of Japanese foreign affiliates. They find that while a large market is the significant determinant for horizontal FDI, labour costs become important for vertical FDI. With regard to other factors, they observe that tariff and distance have opposite effects on location decisions than what is usually obtained in other studies. Salavrakos (2009) attempts to explain FDI of German enterprises by identifying various location-specific, financial, strategic and other motives of these firms. The findings of the paper show that financial, strategic and location specific factors have conventionally been important determinants in the decision of these firms to invest abroad. However, German enterprises now tend to shape their investment strategy on broader factors which influence core developments in the international economy.

Ahamad and Tanin (2010) review the long-run trend of FDI in Bangladesh over the period 1975-2006 to identify determinants of investment decision and also to examine if FDI in Bangladesh is associated with economic growth. The authors find that FDi is concentrated in sectors promoting long-term sustainable growth. Further, over a period of time, supporting policy framework of the government has made Bangladesh and attractive destination for FDI. Examining the impact of macroeconomic factors such as GDP, exchange rate and trade openness on FDI inflows in Norway, Boateng et al. (2015) find that real GDP, sector GDP, exchange rate and trade openness have a positive and significant impact on FDI inflows. Using vector autoregressive and error correction model (VAR/VECM) on quarterly data, they also find that money supply, inflation, unemployment and interest rate are negatively related to FDI. They recommend that governments should design macoreconomic policies in a way that reduces production and transaction costs of MNEs.

Bhasin and Jain (2015) examine the role of host country factors in FDI outflows from India. Employing panel data for fifteen host countries over the period 2000-09, their results show that factors like technology, bilateral investment treaties and FDI openness of the host countries are significant determinants of OFDI from India. An 
analysis of country based studies also reiterates the importance of some determinants of FDI such as market size, labour cost, institutional factors and taxation policies.

\subsection{Conclusion}

This paper attempts to review and examine the existing literature on determinants of FDI, which constitutes an important form of investment for most countries of the world. Just as FDI theories have evolved over a period of time, similarly the significance of different determinants of FDI has also changed over a period of time. The extant literature shows that factors such as market size and per capita incomes have remained important determinants of FDI decisions both traditionally as well as in contemporary times. However, some factors such as resources, trade openness and FDI openness have now become secondary factors influencing FDI. The declining importance of resources as a determinant could be presumably because of the rising importance of market-seeking and efficiency-seeking FDI as compared to resourceseeking FDI. Regarding trade openness and FDI openness, they have become more or less equal for many economies, with increasing gloablisation and liberalisation and emergence of multilaterals institutions such as the WTO. Other factors which were earlier secondary but have now gained prominence as FDI determinants are infrastructure; institutional factors such as corruption and political stability; and tax related variables. The above review provides us insights into the changing aspects of FDI decision-making and can provide useful inputs to policy makers regarding the areas which need focus for creating a congenial climate for FDI.

\section{References}

Ahamad, M. G. \& Tanin, F. (2010). Determinants of and the relationship between FDI and economic growth in Bangladesh. MPRA Paper 20236, University Library of Munich, Germany.

Asiedu, E. (2002). On the determinants of foreign direct investment to developing countries: Is Africa different? World Development, 30(1), 107-119.

Bain, J. S. (1956). Barriers to new competition. MA: Harvard University Press.

Baniak, A., Cukrowski,J. \& Herczynski, J. (2002). On determinants of foreign direct investment in transition economies. Central European University Working Paper No.8, December. 
Bhasin, N. \& Jain, V. (2015). Outward FDI from India: The role of host country factors. Transnational Corporations Review, 7(3), 316-334.

Bhavan, T., Xu, C., \& Zhong, C. (2011). Determinants and growth effect of FDI in South Asian economies: Evidence from a panel data analysis. International Business Research, 4(1), 43-50.

Boateng, A., Xiuping, H., Shaista, N. \& Wu, J. (2015). Examining the determinants of inward FDI: Evidence from Norway. Economic Modelling, 47(C), 118-127.

Boskin, M. J., \& Gale, W. G. (1987) New results on the effects of tax policy on the international location of investment. In Martin Feldstein (ed.) The Effects of Taxation on Capital Accumulation, pp.201-19, Chicago: University of Chicago Press.

Buckley, P.J. \& Casson, M. (1976). The future of the multinational enterprise. Holmes and Meier: London.

Buckley, P.J. \& Casson, M. (1985). The economic analysis of the multinational enterprise: selected papers. Macmillan: London.

Buckley, P.J. (1982). Multinational enterprises and economic analysis. Cambridge University Press, London.

Buckley, P.J. (1988). The limits of explanation: testing the internalisation theory of the multinational. Journal of International Business Studies, 19, 181-93.

Das, K. C. (2013). Home country determinants of outward FDI from developing countries. Margin: The Journal of Applied Economic Research, National Council of Applied Economic Research, 7(1), 93-116.

Diallo, M., Kokouma, S. \& Xu, K. (2013). Attracting Chinese foreign direct investment (FDI) to Africa: Determinants and policies - The case of Guinea. International Journal of Financial Research, 4(4), 52-71.

Dunning, J.H. (1980). Toward an eclectic theory of international production: Some empirical tests. Journal of International Business Studies, 11(1), 9-31. 
Duong, N. M. H. (2015). An investigation of the determinants of US FDI in developed countries, 1982-2010. MPRA Paper 66518, University Library of Munich, Germany.

Erdal D. \& Mahmut, M. (2008). Determinants of foreign direct investment flows to developing countries: A cross-sectional analysis. Prague Economic Papers, University of Economics, Prague, 4, 356-369.

Gastanaga, V. M., Nugent, J. B., \& Pashamova, B. (1998). Host country reforms and FDI Inflows: How much difference do they make? World Development, 26(7), 12991314.

Gropp, R. \& Kostial, K. (2000). The disappearing tax base: is foreign direct investment eroding corporate income taxes? IMF Working Paper No. 173.

Hartman, D. G. (1984). Tax policy and foreign direct investment in the United States. National Tax Journal, 37(4), 475-87.

Hymer, S. (1970). The efficiency (contradictions) of multinational corporations. American Economic Review, 60, 441-48.

José, C. \& Aurora, G. (2009). FDI in the European Union and Mena countries: Institutional and economic determinants. CEFAGE-UE Working Papers 2009_09, University of Evora, CEFAGE-UE (Portugal).

Kayam, S. S. (2009). Home market determinants of FDI outflows from developing and transition economies. MPRA Paper 16781, University Library of Munich, Germany.

Kyoji, F. \& Wei, Y. (2008). How do the location determinants of vertical FDI and horizontal FDI differ? Hi-Stat Discussion Paper Series d07-233, Institute of Economic Research, Hitotsubashi University.

Lien, Y. \& Filatotchev, I. (2015). Ownership characteristics as determinants of FDI location decisions in emerging economies. Journal of World Business, 50(4), 637-650.

Loree, D. W. \& Guisinger, S. (1995). Policy and non-policy determinants of U.S. equity foreign direct investment. Journal of International Business Studies, 26(2), 281-299. 
Lucas, R. E. B. (1993). On the determinants of direct foreign investment: Evidence from East and Southeast Asia. World Development, 21(3), 391-406.

Noorbakhsh, F., Paloni, A. \& Youssef, A. (2001). Human capital and FDI inflows to developing countries: New empirical evidence. World Development, 29(9), 1593-1610.

Nunnenkamp, P. (2001). Foreign direct investment in developing countries: What policymakers should not do and what economists don't know. Kiel Institute for World Economics, Discussion Paper 380.

Porter, M.E. (1985). Competitive advantage: Creating and sustaining superior performance. Free Press: New York, NY.

Salavrakos, I. (2009). determinants of german foreign direct investment: A case of failure? European Research Studies Journal, 12(2), 3-26.

Singh, H. \& Kwang, W. J. (1995). Some new evidence on determinants of foreign direct investment in developing countries. World Bank, Policy Research Working Paper 1531, Washington, D.C.

Sury, N. (2003). Tax sensitivity of inbound foreign direct investment: The Indian experience. M. Phil. Dissertation submitted to the Department of Commerce, Delhi School of Economics, University of Delhi.

Teka, H. G. (2014). Determinants and impediments of FDI inflows in Ethiopia- A firm level investigation. MPRA Paper 55955, University Library of Munich, Germany.

Vernon, R. (1966). International investment and international trade in the product cycle. The Quarterly Journal of Economics, 80(May), 190-207.

Wei, S. (1997). How taxing is corruption on international investors? National Bureau of Economic Research Working Paper 6030.

Youssouf, N. N. (2017). Robust FDI determinants in sub-Saharan African countries. Applied Economics and Finance, 4(5), 21-30. 